\title{
Effect of residual nitrogen and fertilizer nitrogen on sugar beet production in Finland
}

\author{
VeikKo Brummer and ERKKi Aura ${ }^{\mathbf{1}}$ ) \\ Research Centre for Sugar Beet Cultivation, Salo
}

Received 15. 8. 1974

\begin{abstract}
Preliminary determinations for $\mathrm{NO}_{3}-$ and $\mathrm{NH}_{4}-\mathrm{N}$ in topsoil from nitrogen field experiments are discussed. The amounts of residual nitrogen as well as the dates and depth for sampling are considerd in order to investigate the need of fertilizer- $\mathrm{N}$ for continuous sugar beet.

Tops ploughed down as manure increased the available soil nitrogen by about 50 $\mathrm{kg} / \mathrm{ha}$. In practice nitrogen from fertilizer and farmyard manure given to previous beet crops seems to accumulate in the beet soils of Finland.

The concentrations of nitrate and ammonium nitrogen in topsoil were low in the spring of 1972 and $1973 . \mathrm{NO}_{3}-\mathrm{N}$ increased in topsoil during the early summer, and the highest concentrations were found at the beginning of July. Starting from the middle of July the amount of $\mathrm{NH}_{4}-\mathrm{N}$ began to increase both in topsoil and in subsoil. With increasing amounts of nitrogen in the topsoil the sugar content decreases continuously. Also the $\alpha$-amio $\mathrm{N}$ content of beets correlates with the soil nitrogen. There is experimental evidence that $150-180 \mathrm{~kg} / \mathrm{ha}$ nitrate nitrogen in topsoil (residual + fertilizer $\mathrm{N}$ ) in early July gives the best economic result.

The effects of fertilizer and accumulated soil nitrogen on the sugar beet quality together with som other experimental data have been statistically analysed. Regression coefficients indicated that both forms of nitrogen affected the suger content, the $\alpha$ amino $\mathrm{N}$ concentration and clear juice purity, in a similar way.
\end{abstract}

\section{Introduction}

It has been demonstrated both in sugar beet trials and in commercial fields that a part of the nitrogen which has been applied to but not wholly utilized by the previous crop, remains available in the soil (DrAycotT and LAST 1970, JAMES 1971, Reus's and RAO 1971).

Since sugar beet is a very sensitive crop as regards nitrogen, the proper management of fertilizer- $\mathrm{N}$ is an important economic factor for farmers as well as beet sugar factories. Many attempts have recently been made to analyse or predict the approximate need of sugar beet taking into account the seasonally available residual nitrogen in soil determined by different methods (JAMES et al. 1971, Christensen 1973, Reuss et al. 1973). There remain some problems nevertheless, e.g. the appropriate date and method to measure the profile

1) Present address: University of Helsinki, Department of Agricultural Chemistry 
residual nitrogen, the required soil sampling depth for a reliable test, and the significance of soil type as well as organic matter content of the soil (ANDERSON et al. 1972, LuDwick et al. 1973).

Because sugar beet in Finland is usually grown for many years without rotation, and overfertilization has been common practice, the question of the importance of the residual nitrogen, based on determinations for $\mathrm{NO}_{3^{-}}$and $\mathrm{NH}_{4}-\mathrm{N}$ in topsoil and in addition in subsoil, is of current interest. Nowadays, when the top yield is ploughed down on about half the acreage, the significance of tops as manure as well as the effect of residual and ferilizer nitrogen on beet quality has been preliminarily investigated.

\section{Available (residual) nitrogen in soil}

\section{Experiments in 1972}

Three nitrogen series, each consisting of 4 experiments with different experimental design, were carried out during 3-4 years in 1969-72 on four experimental farms, where sugar beet had been grown for many years with the tops ploughed down. A basal NPK-dressing $(30 \mathrm{~N}+98 \mathrm{P}+187 \mathrm{~K}$ $\mathrm{kg} / \mathrm{ha}$ ) was given each spring before harrowing. The nitrogen treatments, according to the experimental lay-out, were applied every year on the same plots following the normal policy in practice.

Soil samples $(0-30 \mathrm{~cm})$ for available nitrogen were taken in 1972 from 12 field experiments, for the first time in early May before the application of fertilizer, and for a second time at the beginning of July. The samples, after immediate drying in open space, were extracted with $0.5 \mathrm{~N} \mathrm{~K}_{2} \mathrm{SO}_{4}$-solution, and analysed from this extract for $\mathrm{NO}_{3}-\mathrm{N}$ (Orion Nitrate Electrode, ion-specific meter, Model 407), and for $\mathrm{NH}_{4}-\mathrm{N}$ (Steam distillation).

One of the trial series carried out in $1970-72$ is examined here in greater detail. The three tested amounts of nitrogen $(75,150$ and $300 \mathrm{~kg} / \mathrm{ha})$ were spread in the spring before harrowing, and given as ammonium nitrate lime $(26 \% \mathrm{~N})$. The effect of the nitrogen was tested both without tops, and with $40 \mathrm{t} / \mathrm{h}$ a tops ploughed down yearly in the previous autumn. The concentrations of ammonium and nitrate-nitrogen in the soil $(\mathrm{mg} / \mathrm{l})$ were low in early May in all treatments. At the beginning of July, $\mathrm{NH}_{4}-\mathrm{N}$ was still almost the same as in the spring, but $\mathrm{NO}_{3}-\mathrm{N}$ had increased considerably (Table 1). Presumably the increasing soil temperature has improved the mineralization of the soil organic nitrogen while the evaporation, together with movements of nitratenitrogen from deeper reserves, has proved a contributing factor. The rather high amount of available nitrogen in early July in the experimental plots was striking when sugar beet was grown for the third year with $30 \mathrm{~kg} / \mathrm{ha}$ as a yearly nitrogen fertilizer.

The $40 \mathrm{t} / \mathrm{ha}$ tops ploughed down every autumn and containing on an average $138 \mathrm{~kg} / \mathrm{ha} \mathrm{N}$, increased the available soil nitrogen in early July by $16 \mathrm{mg} / \mathrm{l}=$ approx. $50 \mathrm{~kg} / \mathrm{ha} \mathrm{N}$. At that time the effect of the tops on the concentrations of the available soil nitrogen seems to decrease with increasing amounts of fertilizer nitrogen (Table 1). 
Table 1. Available nitrogen in topsoil of experimental plots in 1972. Increasing quantities of nitrogen fertilizer were given for sugar beet each year on the same plot. No tops or $40 \mathrm{t} / \mathrm{ha}$ tops were ploughed down in previous autumn. Mean values of 4 experiments started in autumn 1969.

Available nitrogen $(\mathrm{mg} / \mathrm{l})$ in topsoil $(0-30 \mathrm{~cm})$
Without tops

$40 \mathrm{t} / \mathrm{ha}$ tops ploughed down ON 75 N 150 N 300 N ON 75 N 150 N 300 N

$\mathrm{NH}_{4}-\mathrm{N} \mathrm{mg/l,} \mathrm{samples} \mathrm{in} \mathrm{early} \mathrm{May}$ $\mathrm{NO}_{3}-\mathrm{N}$, " , (Before fertilizer application)

Difference between tops and without tops

$\mathrm{NH}_{4}-\mathrm{N} \mathrm{mg} / \mathrm{l}$, samples in early July $\mathrm{NO}_{3}-\mathrm{N}$, , , ,

Difference between tops and without tops

= significant at the $1 \%$ probability level.

$\begin{array}{rrrrrrrr}5 & 5 & 5 & 5 & 6 & 6 & 6 & 7 \\ 11 & 12 & 12 & 18 & 15 & 16 & 17 & 21\end{array}$

$\begin{array}{rrrrrrrr} & & & & +5 & +5 & +6 & +5 \\ 5 & 7 & 6 & 10 & 6 & 6 & 5 & 10 \\ 41 & 70 & 84 & 166 & 56 & 83 & 95 & 161\end{array}$

\section{Experiments in 1973}

The above mentioned experiments were concluded with the harvest in the autumn 1972. To obtain the variations in the soil nitrogen level, the $\mathrm{NO}_{3}-\mathrm{N}$, analysed with Orion Nitrate Electrode, and the $\mathrm{NH}_{4}-\mathrm{N}$, this time analysed with Orion Ammonium Electrode, were determined in summer 1973 in the topsoil $(0-30 \mathrm{~cm})$ and the subsoil $(30-60 \mathrm{~cm})$ from two beet fields, situated in Salo (South-West Finland) about 1 kilometre apart. One of the fields was clay soil, and the other fine sand, the percent organic matter being in both soils about 6.5. Sampling was started in late April. In June and July the samples were taken at about 2 week intervals, subsequently in early September, and for the last time in early November before the autumn ploughing (Fig. 1). Except for tops ploughed down in the previous autumn, the experimental plots were left without fertilizing. The upper line in Figure 1 shows the whole amount of available nitrate + ammonium nitrogen in a $60 \mathrm{~cm}$ deep soil layer. On both fields the highest amounts of $\mathrm{NO}_{3}-\mathrm{N}$ both in top- and subsoil were found in late June - early July, while at the same time and earlier in spring the $\mathrm{NH}_{4}-\mathrm{N}$ concentrations were rather low. Table 2 presents the average figures for the sampling period between 23.4.-4.11. 1973. High rainfall $(119 \mathrm{~mm})$ in the latter half of July and the rapid growth of sugar beet probably decreased the $\mathrm{NO}_{3}-\mathrm{N}$ in topsoil. On the other hand, the amount of $\mathrm{NH}_{4}-\mathrm{N}$ increased later in the growing season, while a considerable part of the soil nitrogen, probably originating from decomposition or mineralization, remained in this form. The concentrations in fine sand were somewhat lower than on clay soil. 


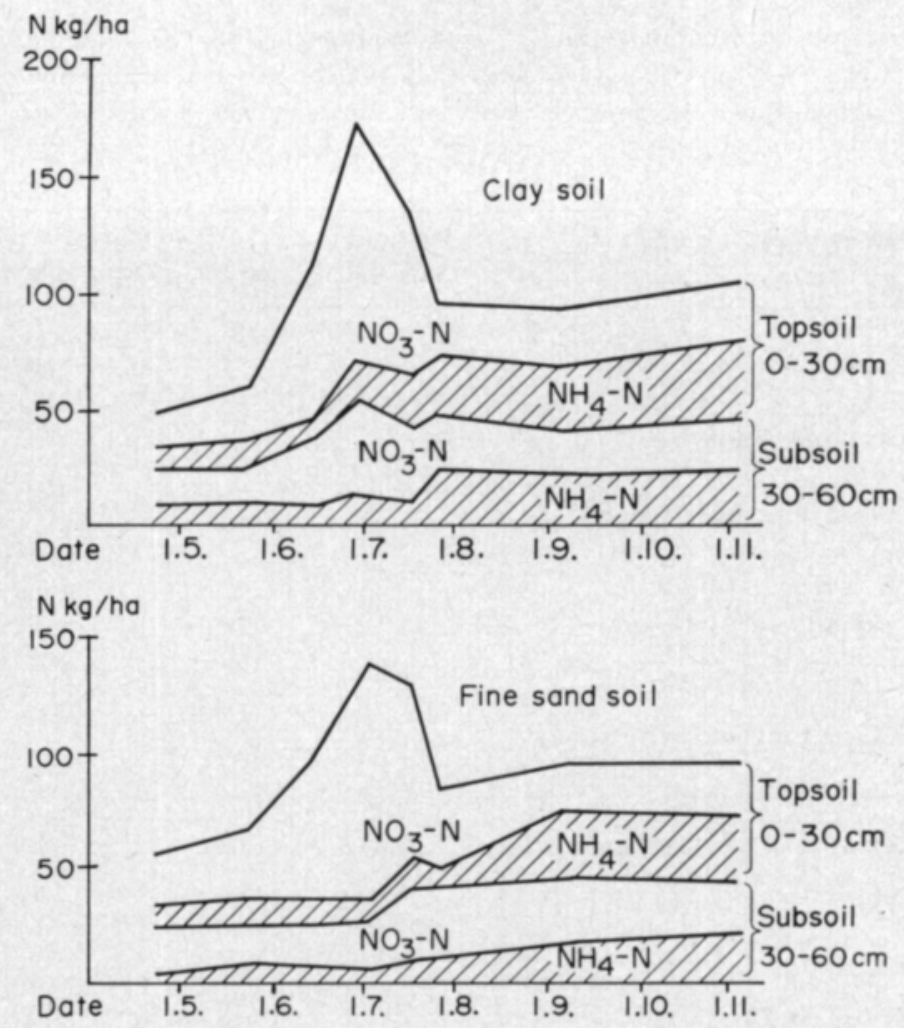

Fig. 1. Available nitrogen in top- and subsoil of two unfertilized beet fields in summer 1973. The upper line is giving available nitrogen in $0-60 \mathrm{~cm}$.

Table 2. The average amounts of available $\mathrm{NO}_{3}-$ and $\mathrm{NH}_{4}-\mathrm{N}$ in top- and subsoil on two unfertilized beet fields, and the extreme values during 23.4.-4.11.1973.

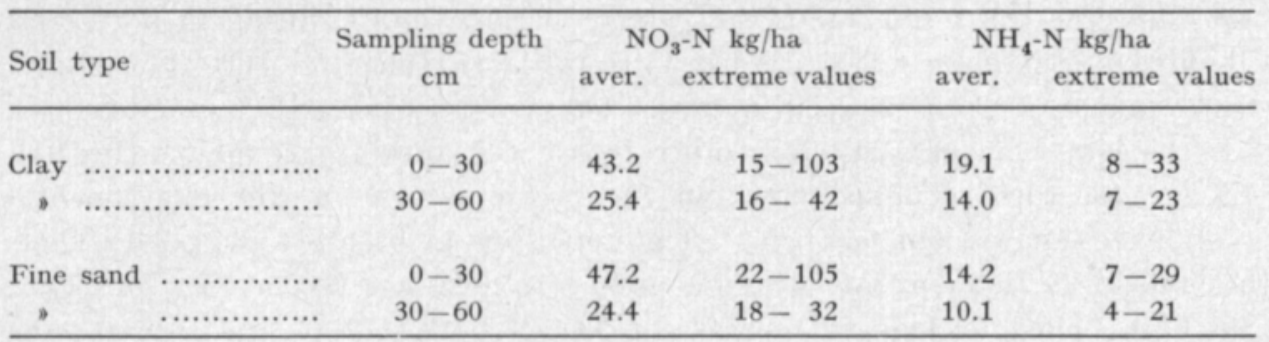

Situation on farms

Soil analyses carried out on $\mathbf{2 5}$ old beet fields in the Salo Sugar Factory area early July 1973 indicated that the average concentration of available nitrogen $\left(\mathrm{NO}_{3}-\mathrm{N}+\mathrm{NH}_{4}-\mathrm{N}\right)$ in topsoil was $283 \mathrm{~kg} / \mathrm{ha}\left(259 \mathrm{~kg} \mathrm{NO} \mathrm{NO}_{3}-\mathrm{N}+24\right.$ $\mathrm{kg} \mathrm{NH}_{4}-\mathrm{N}$ ), the range of total variation being $123-551 \mathrm{~kg} / \mathrm{ha}$. The figures for available nitrogen seem to bear a relation to the fertilizing practice on these 
Table 3. Available nitrogen in topsoil on 25 farms, and $\mathbf{N}$ fertilizing practice of these farms in 1973

No. of farms

in the class
Available nitrogen $\left(\mathrm{NH}_{4}+\right.$ $\left.\mathrm{NO}_{3}-\mathrm{N}\right) \mathrm{kg} /$ ha in early July in topsoil $(0-30 \mathrm{~cm})$

\section{Applied fertilizer nitrogen}

in spring aver. $\mathrm{kg} / \mathrm{ha}$

\begin{tabular}{|c|c|c|}
\hline 2 (2) & $100-149$ & 127 \\
\hline 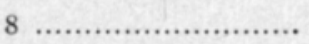 & $150-199$ & 162 \\
\hline 6 & $200-299$ & 170 \\
\hline 6 & $300-399$ & 222 \\
\hline & $400-600$ & $\left.194^{1}\right)$ \\
\hline
\end{tabular}

1) On these farms sludge manure has been given to sugar beet for several years.

farms (Table 3). Judging by this material it seems likely that some of the nitrogen from fertilizer and manure given to but not utilized by the previous beet crop has accumulated in the soil.

\section{Effect on yield and sugar content}

Only the tops (40 t/ha), when ploughed down, increased (11 experiments in $1970-72$ ) the root yield by $3.0 \pm 1.6 \mathrm{t} / \mathrm{ha}$ on an average (Fig. 2). The three amounts of $\mathrm{N}$ fertilizer without tops gave on an average $2.1 \mathrm{t} / \mathrm{ha}$ more beets than the control (without tops or nitrogen fertilizing), and nitrogen with tops

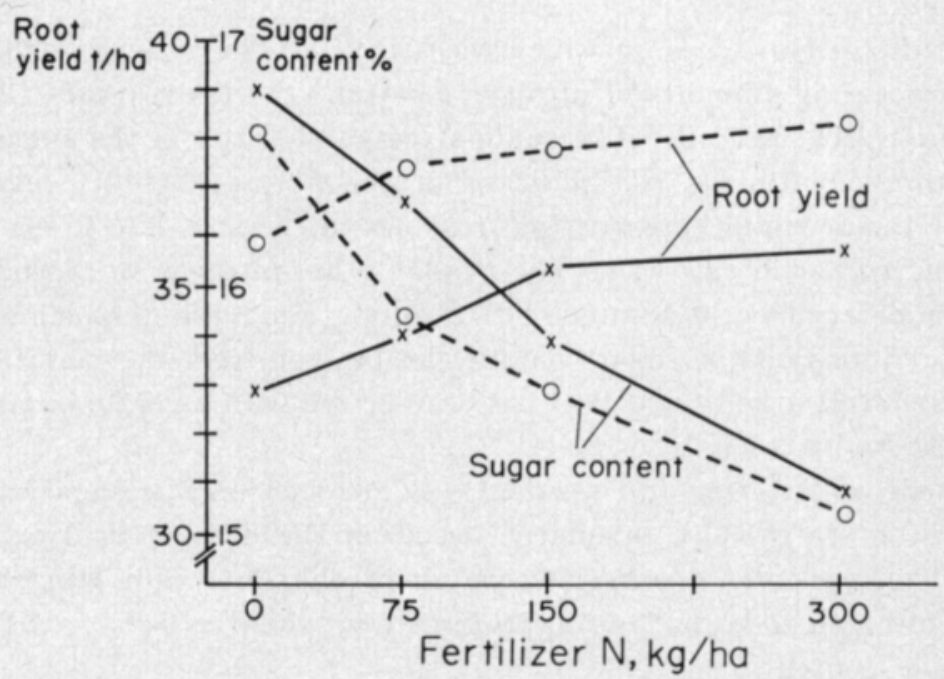

Fig 2. Effect of fertilizer nitrogen on root yield and sugar content. Mean values of 11 experiments in $1970-72$. 


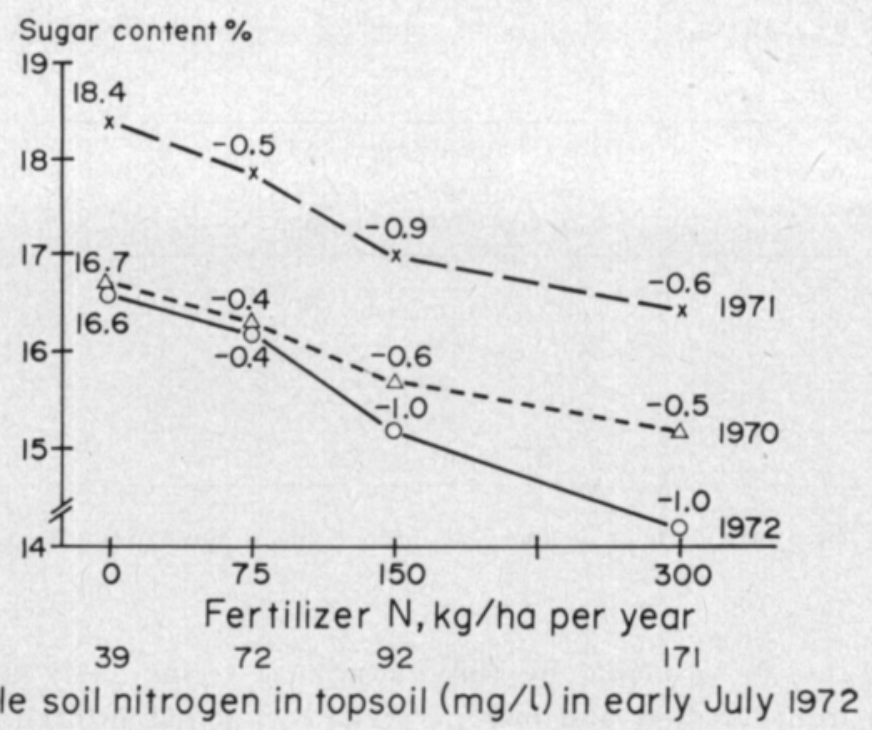

Fig. 3. With prolonged nitrogen fertilizing of the same plots nitrogen accumulates in soil, which appears as a cumulatively continuing decrease in sugar content. Mean values of 2 experiments in $1970-72$.

an additional average of $4.9 \mathrm{t} / \mathrm{ha}$. This means that the difference $(2.8 \mathrm{t} / \mathrm{ha})$, which is the effect of the tops, has been about the same as that for tops alone without nitrogen fertilizer.

On the other hand the nitrogen in the tops decreased the sugar content. The biggest difference $(-0.46 \%$-units, significant at the $1 \%$ probability level) between tops and no tops was found with the smallest amount $(75 \mathrm{~kg} / \mathrm{ha})$ of nitrogen (Fig. 2).

The results of two trials, in which the same plots have been fertilized with the same increasing amounts of nitrogen for three successive years (1970-72), are very interesting (Fig. 3). The cumulative yearly drop in the sugar content of the various treatments is significant at the $\mathbf{5} \%$ probability level. It is likely that the accumulating nitrogen residues in the soil, due to the nitrogen fertilization, appear in this way. The available soil nitrogen in topsoil in these trials was determined in summer 1972 only. The vital importance of the climatic conditions on the sugar content can be seen from the variation in the data of the control, when sugar beet has been grown with a yearly basal nitrogen dressing $(30 \mathrm{~kg} / \mathrm{ha} \mathrm{N})$ only.

The effect of fertilizer and residual soil nitrogen on the sugar content of beets has been statistically calculated based on the data in field experiments (Fig. 4). The regression coefficients are about the same indicating that both origins of nitrogen have had an approximately similar effect on the decrease of the sugar content.

Figure 5 shows how difficult it is for a farmer observing the obvious growth of tops due to the increased use of nitrogen, to realize that root and sugar yields are not following the steep rising curve of the top yield. The almost straight line drop in the sugar content, payment according to the individual sugar content 


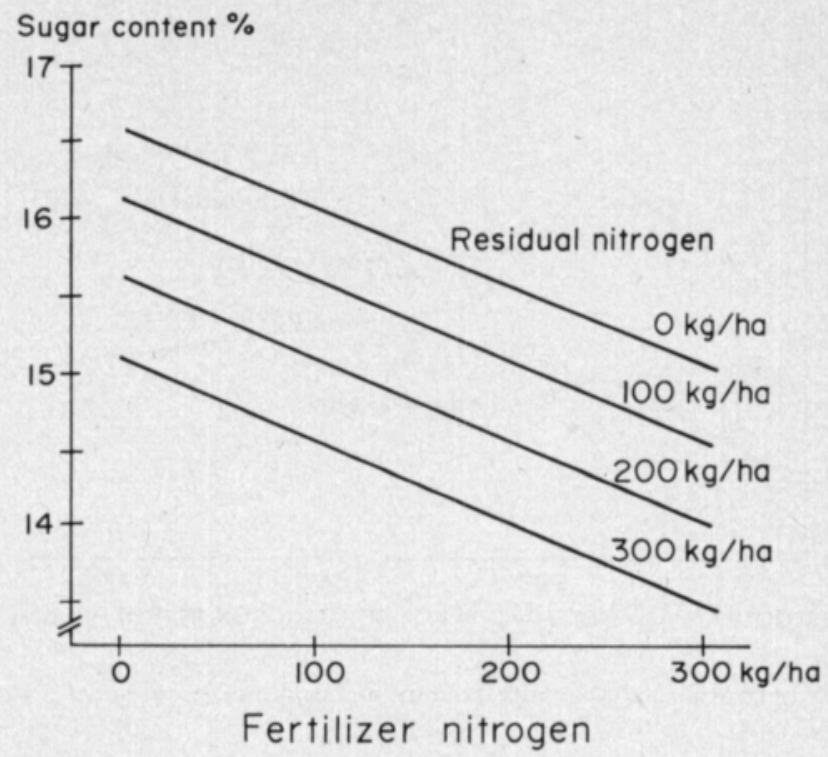

Fig. 4. Effect of fertilizer $\left(x_{1}\right)$ and residual soil $\left(x_{2}\right)$ nitrogen on the sugar content $(y)$ of beets. 11 experiments in 1972.

$$
y=-0.00555 \times x_{1}-0.00526 \times x_{2}+16.59 . R^{2}=0.560 * * *
$$

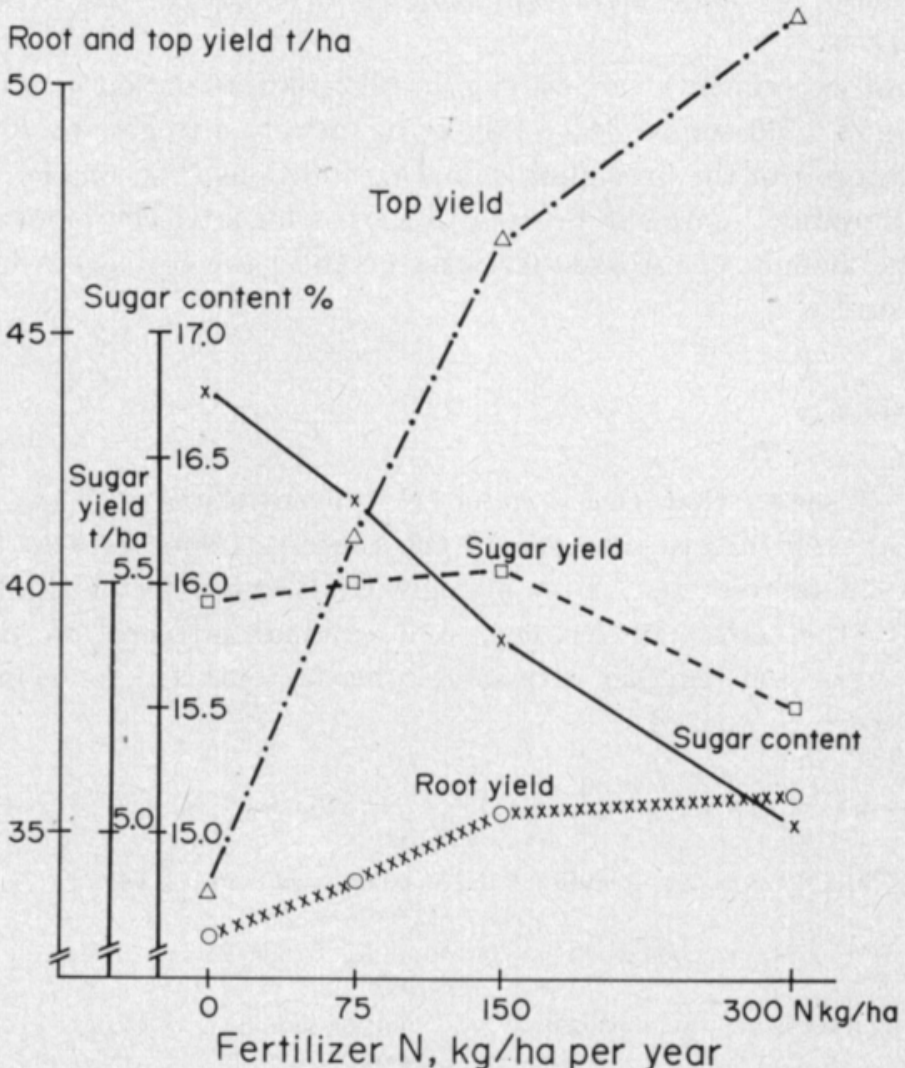

Fig. 5. Results of nitrogen trials, in which the same plots have been fertilized with corresponding amounts of nitrogen. Mean values of 11 experiments in $1970-72$. 


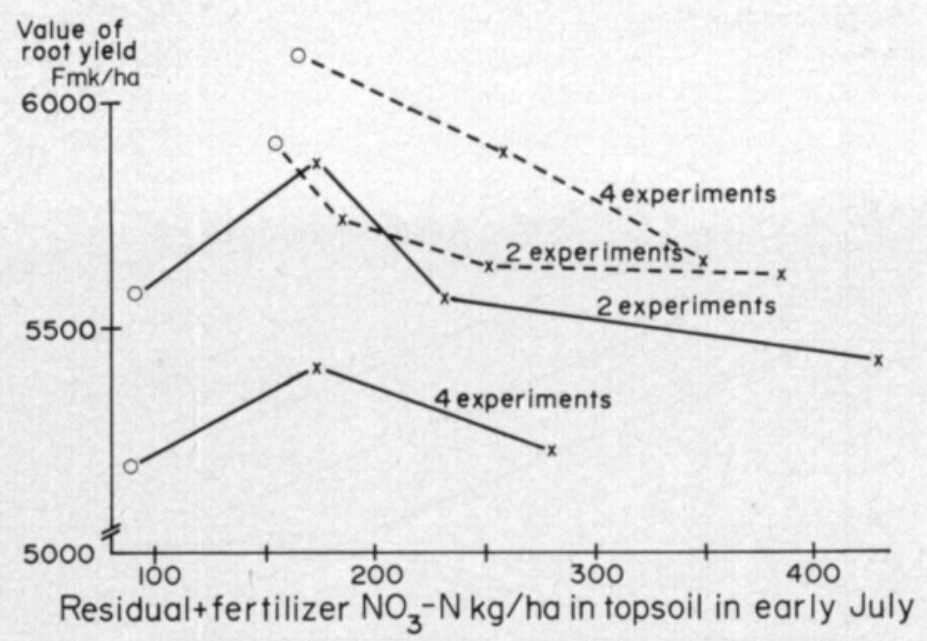

Fig. 6. Relation between available nitrogen in soil and the economical value of root yield. 12 experiments in 1972.

$0=$ No fertilizer nitrogen in spring No tops in previous autumn

$\mathbf{x}=$ Fertilizer nitrogen in spring $40 \mathrm{t} / \mathrm{ha}$ tops ploughed down

with premiums for high sugar, are making an excessive use of nitrogen uneconomical.

The field experiments carried out in 1972 indicated that in early July the topsoil should hold about $150-180 \mathrm{~kg} / \mathrm{ha}$ nitrate-nitrogen to give the best economical result in the prevailing climatic conditions (Fig. 6). For the present this approximative figure can be used as a basis for later comparison indicating whether the amount of nitrogen fertilizer given in the spring has been approximately correct.

\section{Technical quality}

Figure 7 shows that the $\alpha$-amino $\mathrm{N}$ concentration of beets was closely related to the soil nitrate-nitrogen in the topsoil. Using data of field experiiments in 1972 (60 treatments from nitrogen trials) it has been possible to analyse statistically the effect of fertilizer and residual nitrogen on the technical quality of sugar beet together with some other factors. The following regression equations were computed:

(1) Sugar content $=0.00526 \times \mathrm{N}_{\mathrm{s}}-0.00555 \times \mathrm{N}_{\mathrm{f}}+0.0365 \times$ pl.dens. +13.77 $\mathrm{R}^{2}=0.672 * * *$

(2) $a$-amino $\mathrm{N}=0.128 \times \mathrm{N}_{\mathrm{s}}+0.0877 \times \mathrm{N}_{\mathrm{f}}-0.606 \times$ pl.dens. +64.6 $\mathrm{R}^{2}=0.757 * * *$

(3) $\mathrm{K}_{\mathrm{b}}=0.0176 \times \mathrm{N}_{\mathrm{s}}+0.00424 \mathrm{~N}_{\mathrm{f}}+0.00550 \times \mathrm{K}_{\mathrm{s}}+0.0031 \mathrm{x} \times$ pl.dens. +3.75 $\mathrm{R}^{2}=0.880 * * *$

(4) $\mathrm{Na}_{\mathrm{b}}=0.00544 \times \mathrm{N}_{\mathrm{s}}+0.0000838 \times \mathrm{N}_{\mathrm{f}}-0.0288 \times$ pl.dens. +2.88 $\mathrm{R}^{2}=0.453 * * *$

(5) $\mathrm{CJP}=-0.0113 \times \mathrm{N}_{\mathrm{s}}-0.0109 \times \mathrm{N}_{\mathrm{f}}-0.00676 \times \mathrm{K}_{\mathrm{s}}+0.0430 \times$ pl.dens. +94.2 $\mathrm{R}^{2}=0.696 * * *$ 


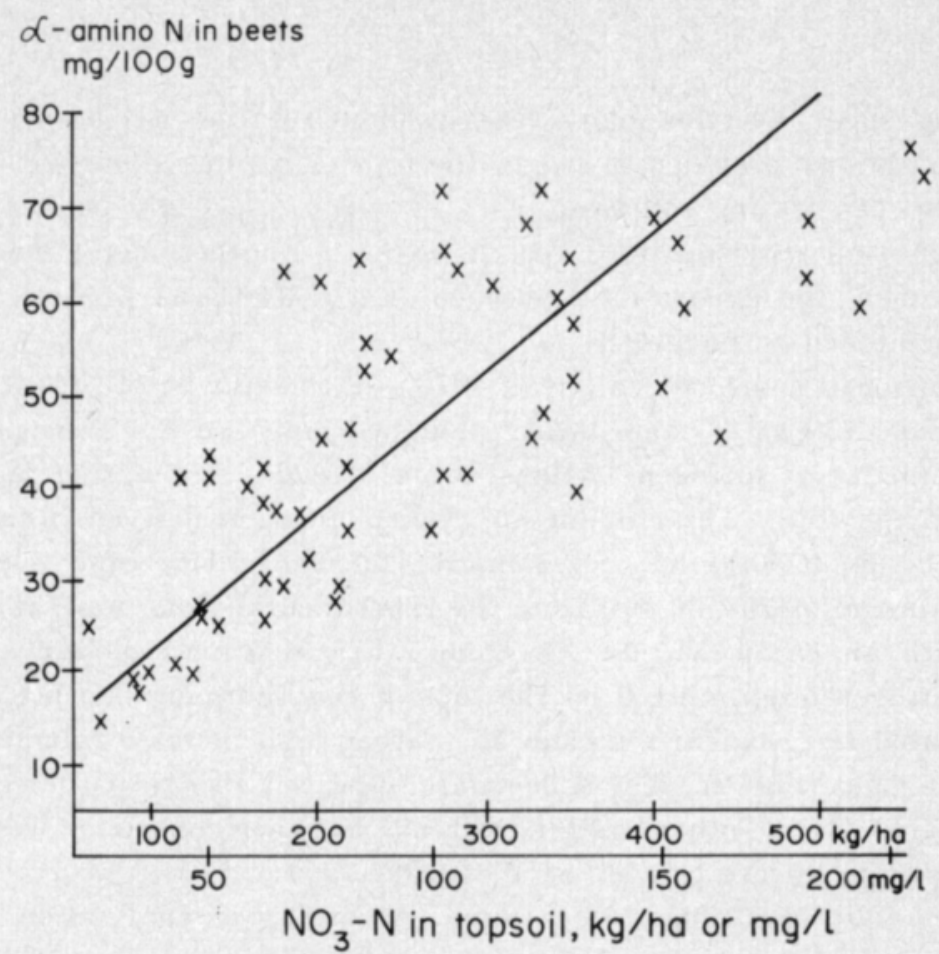

Fig. 7. Correlation between nitrate-nitrogen concentration in topsoil (residual + fertilizer N) and the $\alpha$-amino $\mathrm{N}$ concentration of beets, 11 experiments in 1972.

$a$-amino $\mathrm{N}=0.152 \times \mathrm{N}(\mathrm{kg} / \mathrm{ha})+6.49$

$\mathrm{r}^{2}=0.567 * * *$

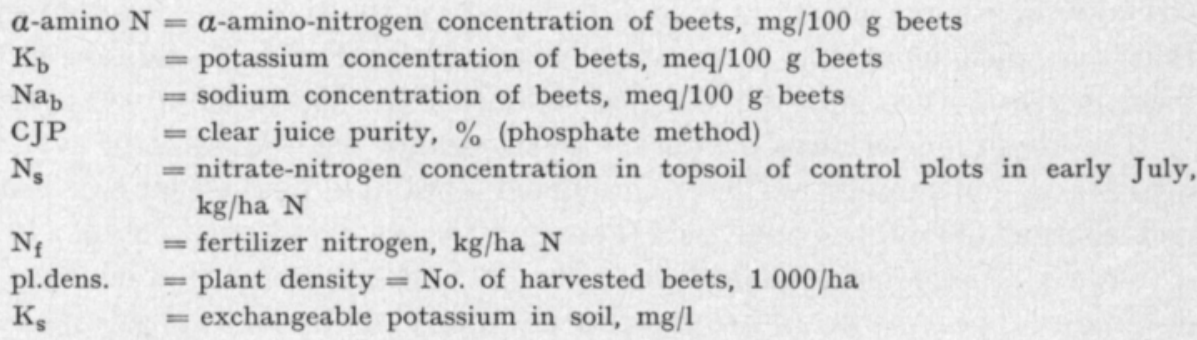

The coefficients of determination were fairly high, with the exception of sodium because the sodium concentration of the soil had not been analysed. Regarding the sugar content, the regression coefficients for residual and fertilizer nitrogen are nearly the same. This confirms that the nitrogen in the topsoil has had an almost similar effect regardless of the source of the nitrogen (residual or fertilizer $\mathrm{N}$ ). Their respective effect on the $\alpha$-amino $\mathrm{N}$ concentration of the beets as well as on the clear juice purity was also about the same. The available soil nitrogen has likewise had a noticeable effect on the potassium concentration of the beets. 


\section{Discussion}

Growing sugar beet for many years without rotation has been possible in Finnish conditions probably owing to the tops or manure ploughed down and to the deep penetrating soil frost, both of which, especially on heavier soils, improve the soil structure to a certain extent. Another factor has been, at least until now, the almost total absence of nematodes as well as of various other difficult soil-borne insects.

In 11 nitrogen trials carried out in $1970-72$ the $40 \mathrm{t} /$ ha of tops, containing on an average $138 \mathrm{~kg} \mathrm{~N}$, were yearly ploughed down on the same plots while various amounts of nitrogen fertilizer were spread every spring alone or in addition to the tops. The amount of residual nitrogen derived from the tops proved to be about $50 \mathrm{~kg} / \mathrm{ha}$. Soil samples, collected in late June - early July in 1972 from topsoil $(0-30 \mathrm{~cm})$ from the experimental plots, were analysed for $\mathrm{NO}_{3}-\mathrm{N}$ with an Orion Nitrate Electrode. This relatively modest amount of residual nitrogen originating from the tops, if this sampling depth is adequate for ar reliable test, can not explain the rather high increase (about $3.0 \mathrm{t} / \mathrm{ha}$ ) in the root yield (Fig. 2). The soil nitrate appeared also to be decreasing the sugar content. On the other hand, fertilizer $\mathrm{N}$ has been considered less effective than soil profile nitrate (REUSs et al. 1973).

Beet tops are also rich in potassium. According to analyses of beet tops used in the trials, the values of potassium $(4.2 \% \mathrm{~K}$ in dry matter) seem to be higher than in many other European countries. Since with the basal PKdressing $187 \mathrm{~kg} / \mathrm{ha} \mathrm{K}$ was yearly given, and in 40 tons of tops on an average $230 \mathrm{~kg} /$ ha more $\mathrm{K}$, the remarkable yield increase is presumably not based on the potassium either. In another trial series (unpublished results), the potassium effect of 40 tons of tops used as K-manure proved to be equivalent to their contents of potassium. Presumably the explanation is to be found in the soil structure improving effect of the tops. A long-term rotation series has confirmed that continued ploughing down of the tops $(40 \mathrm{t} / \mathrm{ha})$ had in addition to the yield increase, also improved the porevolume of the topsoil (BRUMMER 1972).

The use of ion selective membrane electrodes for determination of available nitrogen in soil profiles has been considered a suitable method for soil testing and routine laboratory analysis (Jensen 1970, Selmer-Olsen et al. 1971). According to experiences gained in $1972-73$, both nitrate and ammonium ion electrodes appear to be rather easy to use and to be relatively reliable.

Recent investigations (LUDWICK et al. 1973, REuss et al. 1973) have indicated that in the USA on irrigated soils deep sampling $(90-150 \mathrm{~cm})$ is necessary. As nitrate nitrogen remains mostly in the soil solution, it is highly mobile in the soil profile. About $50 \%$ of the $\mathrm{NO}_{3}-\mathrm{N}$ has been found in the topsoil $(0-30$ $\mathrm{cm})$, although there were big variations between the different farm sites. The major problems with nitrate testing in Finnish conditions seem to be the date of soil sampling and the sampling depth. If deeper sampling than $50-60 \mathrm{~cm}$ is needed, a special soil coring and sampling machine is necessary.

The preliminary determinations of $\mathrm{NO}_{3}$ - and $\mathrm{NH}_{4}-\mathrm{N}$ on two beet fields in top- and subsoil $(0-30,30-60 \mathrm{~cm})$ throughout the season in 1973 indicate that especially the sampling date causes variation (Fig. 1). The importance of 
available $\mathrm{NH}_{4}-\mathrm{N}$ has not been investigated in detail. On an average, for the whole period $(23.4 .-4.11 .1973)$ there was $\mathrm{NH}_{4}-\mathrm{N}$ in clay soil $32.5 \%$ from the total nitrogen, and in fine sand soil $25.3 \%$ (Table 2). It is probable that the nitrate alone would give the necessary information about the available soil nitrogen.

May and June are usually rather dry, whereas there is more rain later in the season. The average precipitation for the growing period (V-IX) in SouthFinland is about $250-300 \mathrm{~mm}$. Presumably the leaching of the nitrate nitrogen into deeper layers is influenced by rain as well as by the soil type, percent organic matter, and the prospective denitrification, i.e. the delayed utilization of fertilizer nitrogen given in spring and remaining over the winter. Hence it is difficult in Finnish conditions to predict the supply of nitrogen for the following sugar beet crop on the basis of the amount of available nitrogen in the middle of the summer. It would be necessary to investigate the profile nitrate levels with a deeper sampling depth than $60 \mathrm{~cm}$ as well as various sampling dates on commercial fields, so as to be able to estimate the influence of seasonally available nitrogen as well as nitrogen released by decomposition or mineralization of organic matter and crop residues in beet soils. Another analysis of beet soils in West-Finland seemed to indicate that the $\mathrm{NO}_{3}-\mathrm{N}$ concentrations were lower on fine sand soils that were rather poor in humus, compared with clay and organic soils rich in organic matter. As to the release of nitrogen through the mineralization of organic matter it tends to vary from year to year depending upon soil temperature and moisture conditions (Christensen 1973).

During the years $1972-73$ there were large amounts of available nitrogen to be found in soils between late June - early July. To ascertain the suitability of this period for soil sampling further experience is required, also from rainy growing periods. Until further notice the experimental evidence that $150-$ $180 \mathrm{~kg} / \mathrm{ha}$ of nitrate nitrogen in topsoil in early July is giving the best economic result, might serve as an approximative basic figure.

The investigations carried out in $1972-73$ are only preliminary. Nevertheless it has been demonstrated that also in Finnish beet soils cumulative reserves of available nitrogen can be found, due to nitrogen fertilization, ploughing down of tops or using large amounts of manure for continuous sugar beet (Tables 1 and 3, Fig. 3). The residual nitrogen has also proved to be as harmful as fertilizer nitrogen to the beet quality (sugar content, $\alpha$-amino $\mathrm{N}$ and clear juice purity).

\section{LITERATURE}

Anderson, F. N., Peterson, G. A. \& Olson, R. A. 1972. Uptake patterns of ${ }^{15}$ tagged nitrate by sugarbeets as related to soil nitrate level and time. J. Amer. Soc. Sugar Beet Technol. 17: $42-48$.

BRUMmer, V. 1972. Sokerijuurikas ja esikasvikysymys. Sason Uutiset, 14, 2: 2-6.

Christensen, N. W. 1973. Nitrogen management for maximum sugarbeet production. Montana Farmer Stockman, 60, No. 24. Repr. 5 p.

Draycotr, A. P., \& LAst, P. J. 1970. Effect of previous cropping and manuring on the nitrogen fertilizer needed by sugar beet. J. Agric. Sci. Camb., 74: 147-152. 
James, D. W. 1971. Soil fertility relationships of sugarbeets in Central Washington: Nitrogen. Wash. Agric. Exp. Stat. Techn. Bull. 68:1-14.

- - Richards, A. W., Weaver, W. H. \& Reeder, R. L. 1971. Residual soil nitrate measurement as a basis for managing nitrogen fertilizer practices for sugarbeets. J. Amer. Soc. Sugar Beet Technol. 16: 313-322.

JENSEN, J. 1970. Bestemmelse af nitrat i jordekstrakter med en nitratspecifik elektrode. Tidsskr. Planteavl. 74: 145-150.

Ludwick, A. E., Reuss, J. O. \& Giles, J. F. 1973. Distribution of soil nitrates in Eastern Colorado fields prior to planting sugarbeets. Colo. State Univ. Fort Collins Exp. Sta. Progr. Rep. 40: 1-3.

REUSS, J. O. \& RAO, P. S. C. 1971. Soil nitrate nitrogen levels as an index of nitrogen fertilizer needs of sugarbeets. J. Amer. Soc. Sugar Beet Technol. 16: 461-470.

- - Ludwick, A. E. \&. Giles, J. E. 1973. Prediction of nitrogen fertilizer requirements of sugarbeets by soil analysis. Colo. State Univ. Fort Collins Exp. Sta. Progr. Rep. 39: $1-4$.

Selmer-Olsen, A. R., Øien, A., Baerug, R. \& Lyngstad, I. 1971. Pretreatment and storage of soil samples prior to mineral nitrogen determination. Acta Agric. Scand. 21: $57-63$.

\title{
Selostus
}

\section{Maan typpi sokerijuurikkaan viljelyssä Suomessa}

\author{
VEIKKo BRUMmer ja ERKKI AURA') \\ Sokerijuurikkaanviljelyn Tutkimuskeskus, Salo
}

Juurikassokeritehtaiden koetiloilla suoritettujen kenttäkokeiden avulla tutkittiin maan luontaisen typen, typpilannoituksen ja naatin maahan kynnön vaikutusta sokerijuurikkaan satoon ja kemialliseen laatuun. Koesarjoja oli 3, joista jokainen suoritettiin neljällä koepaikalla. Kokeet aijaitsivat 3-4 vuotta samalla paikalla v. 1969-72.

Vuonna 1972 toukokuun alussa ennen lannoitteiden levitystä ruokamultakerroksesta otetut maanäytteet osoittivat ammonium- ja nitraattityppipitoisuuden olevan koemaissa varsin alhaisen. Heinäkuun alussa otettujen maanäytteiden ammoniumtyppipitoisuus oli lähes sama kuin toukokuun alussa, mutta $\mathrm{NO}_{3}-\mathrm{N}$-pitoisuus oli kohonnut suuresti. Myös ruudut, jotka olivat saaneet typpeä ainoastaan peruslannoituksen mukana (N $30 \mathrm{~kg} / \mathrm{ha}$ ) sisälsivät heinäkuun alussa huomattavan paljon käyttökelpoista typpeä.

Jatkuva naatin maahan kyntő lisäsi käyttōkelpoisen typen määrää maassa noin $50 \mathrm{~kg}: 1 \mathrm{lla} / \mathrm{ha}$, kun typpilannoitetta ei käytetty lainkaan. Naatilla oli huomattava juurisatoa nostava vaikutus (n. 3 tn/ha). Juurikkaan kasvun paraneminen johtunee lähinnä naatin maahan kynnön edullisesta vaikutuksesta maan fysikaaliseen tilaan. Keväisin juurikkaalle annettu typpilannoitus nosti hyvin voimakkaasti naattisatoa. Juurisadon kohoaminen typen ansiosta jäi huomattavasti heikommaksi.

Luontainen ja lannoitetyppi alensivat erittäin selvästi sokeripitoisuutta ja juurikkaasta saatavan kirkasmehun puhtautta. Typpi lisăsi juurikkaan aminotyppi-, kalium- ja natriumpitoisuutta. Regressiolaskenta osoitti, että luontaisella ja lannoitetypellä oli lähes yhtä voimakas vaikutus juurikkaiden sokeripitoisuuteen, aminotyppipitoisuuteen ja kirkasmehun puhtauteen. Ruokamultakerroksessa heinäkuun alussa olevan nitraattitypen mäårän ja juurikkaan aminotyppipitoisuuden välillä oli hyvin kiinteä vuorosuhde. Juurisadon arvo oli suurimmillaan, jos heinäkuun alussa, jolloin sokerijuurikas alkaa kasvaa hyvin kiihkeästi, oli tarjolla käyttökelpoista typpeä n. $150-180 \mathrm{~kg} / \mathrm{ha}$.

Heinäkuun alussa 25 tilalta vuonna 1973 otettujen maanäytteiden analyysien mukaan oli juurikasmaan muokkauskerroksessa keskimäärin käyttökelpoista typpeä $283 \mathrm{~kg} / \mathrm{ha}(259 \mathrm{~kg}$

1) Nykyinen osoite: Helsingin yliopisto, Maanviljelyskemian laitos 
$\mathrm{NO}_{3}-\mathrm{N}+24 \mathrm{~kg} \mathrm{NH}-\mathrm{N}$ ). Vaihteluväli oli $123-551 \mathrm{~kg} / \mathrm{ha}$. Ilmeisesti hyvin suuret typen määrät viljelijöiden juurikaspellossa johtuvat jatkuvasta runsaasta lannoitetypen tai kotieläinten lannan käytōstä.

Vuonna 1973 seurattiin ammonium- ja nitraattitypen esiintymistä hienohieta- ja hietasavimaassa lannoittamattomassa osassa juurikaspeltoa. Molemmissa maissa kesän puoliväliin saakka oli ammoniumtyppeä vähän sekä pinta- $(0-30 \mathrm{~cm})$ että pohjakerroksessa $(30-60 \mathrm{~cm})$. Keväällä nitraattityppipitoisuus oli alhainen, mutta suureni voimakkaasti alkukesăn aikana pintamaassa. Kesä-heinäkuun vaihteen jälkeen alkoi nitraattityppipitoisuus kuitenkin nopeasti aleta johtuen ilmeisti juurikkaan nopeasta ravinteiden otosta ja tähän aikaan sattuneista runsaista sateista. Ammoniumtyppipitoisuus sen sijaan kohosi loppukesän aikana.

Alustavat tulokset osoittavat, että kuivahkon sään vallitessa näyttäisi kesä-heinäkuun vaihteessa mitattu nitraattitypen määrä antavan hyvän kuvan juurikkaalle tarjolla olevan käyttökelpoisen typen määrästä. Analysoimalla myös juurikkaan aminotyppipitoisuus saadaan varsin luotettava käsitys juurikasmaassa vallinneesta typpitilanteesta. 